\title{
Hose Line Device
}

National Cancer Institute

\section{Source}

National Cancer Institute. Hose Line Device. NCI Thesaurus. Code C50280.

A flexible tube designed to carry a fluid. 